\title{
Assessment of Water Pollution Status of Selected Fishery Harbours located in the Southern Province of Sri Lanka
}

\author{
K. A. W. S. Weerasekara ${ }^{1, \#, ~ O . ~ M . ~ M . ~ D . ~ J a y a m p a t h i ~}{ }^{2}$, N. D. Hettige ${ }^{1}$, \\ S. A. M. Azmy ${ }^{1}$, A. A. D. Amarathunga ${ }^{1}$, W. D. N. Wickramaarachchi ${ }^{1}$, \\ M. D. S. R. Maddumage ${ }^{1}$, J. K. P .C. Jayawardena ${ }^{1}$, S. R. C. N. K. \\ Narangoda $^{1}$, R. M. G. N. Rajapaksha ${ }^{2}$ and N. P. P. Liyanage ${ }^{2}$ \\ ${ }^{1}$ Environmental Studies Division, \\ National Aquatic Resources Research and Development Agency (NARA), \\ Crow Island, Colombo 15, Sri Lanka \\ ${ }^{2}$ Faculty of Animal Science and Export Agriculture, \\ Uva Wellassa University, Badulla, Sri Lanka \\ \#Corresponding Author: \\ Tele:0112521009; E-mail: shyamalikaww@gmail.com
}

\begin{abstract}
The objective of this study was to determine the current status of water quality in three selected fishery harbours named Hikkaduwa, Galle, and Hambantota located in the Southern coastal stretch of the country. It also aimed to provide recommendations to prevent harbour water pollution and minimize post-harvest loses due to spoilage and finally to upgrade the quality of fish for human consumption. Field visits were carried out for three months period from May to July 2014. Three sampling locations from each fishery harbour were selected and total of 14 physicochemical parameters of water quality were measured to identify the pollution levels. Assessments were also carried out to evaluate microbial contaminations. Results revealed that $\mathrm{pH}$, dissolved oxygen, salinity, nitrate- $N$, nitrite- $N$ and electrical conductivity were within the acceptable limits in all harbours. Average BOD (9.67 \pm 0.70$)$, (7.10 \pm 0.43$)$, $(9.17 \pm 0.25) \mathrm{mg} / \mathrm{L}, \mathrm{COD}$ (719.51 \pm 161.63$),(926.50 \pm 93.50),(840.20 \pm 104.80) \mathrm{mg} / \mathrm{L}$ and oil \& grease $(13.1$ $\pm 0.60),(17.90 \pm 0.20),(17.80 \pm 1.20) \mathrm{mg} / \mathrm{L}$ in Hikkaduwa, Galle, and Hambantota showing high level of water pollution of those harbours. MPN values of fecal coliforms (per $100 \mathrm{ml}$ ) were ranged between 1633 and 2400, which also exceeded the recommended standards for harbour waters. The study revealed that the water quality of the fishery harbours were degraded and are subjected to chemical pollution, oil pollution, and microbial contamination.
\end{abstract}

KEYWORDS: Chemical oxygen demand, Fishery harbour pollution, Microbial contamination, Oil \& grease 


\section{Introduction}

Sri Lanka is an island located between latitudes $5^{\circ} 55^{\prime}$ and $9^{\circ} 51^{\prime} \mathrm{N}$, longitudes $79^{\circ}$ $41^{\prime}$ and $81^{\circ} 54^{\prime} \mathrm{E}$, and is extending approximately over $65,610 \mathrm{~km}^{2}$ with a coastline about $1,620 \mathrm{~km}$ (CZMP, 1990).In ancient times, prior to colonial period and to the independence gained in 1948, the country's centres of civilization were located in the mountainous interior and the coastal areas left as a buffer against invasions from abroad. However, it has gradually changed and many people began to migrate coastal areas to take advantages of economic and educational opportunities (CZMP, 1990). In Sri Lanka, 14 out of 25 administrative districts are coastal districts which cover approximately $44.5 \%$ of total area of the country while $56.7 \%$ of the country's population lives in these coastal districts (Census of Sri Lanka, 2012).

The economic importance of coastal areas has increased further with the growth of human settlements and the development of commercial harbours, fishery harbours, landing facilities, river training and outfall schemes, transport, communications, recreational facilities and tourism (CZMP, 1990). These accelerating urbanization and industrialization in coastal areas lead to substantial increases in the aggregate amounts of wastes produced and thus waste management and coastal water pollution control are of increasing concern (CZMP, 2007). Urban pollutants of heavy metals, petro-chemicals, sediments and fecal matter degrade marshes, estuaries, lagoons, coral reefs and other coastal habitats and directly threaten the sustainability of near shore fisheries.

Fishery harbour is a complex centre of activities which are potential waste generators and thus considered as a hot spot of coastal pollution (Niroshana et al., 2013). Pollution of harbour waters due to dumping of untreated sewage in contiguous waters and the harbour basin is often the most common causes for seafood-related diseases and epidemics. Harbour water quality is heavily influenced by human activity not only within the harbour complex but also in the surrounding environment as well. As the fishery harbour and its contiguous waters are part of the coastal zone, pollution of the harbour directly affects the coastal zone and vice versa (Scoiortino, 2010).

Fishery industry in Sri Lanka plays an important role in the country's economy while contributing around $1.2 \%$ to the GDP and nearly $70 \%$ to the animal protein intake in the country. The report compiled by the Ceylon Chamber of Commerce (n. d.) Stated that, the fisheries sector provides direct and indirect employment to around 650,000 people and is directly linked with the lives of approximately $50 \%$ of the population who resides in the coastal belt. Fisheries sector contribution to the total export earnings of the country is around $2.5 \%$. The fisheries sector has a significant scope for increasing the contribution to the national economy, exploiting the huge untapped potential. 
However, the fish production suffers post-harvest loses due to spoilage from bacteria and chemical reactions. The use of contaminated water for fish handling in fishery harbours may be one of the main reasons for this situation.

Therefore, the main objective of this study was to determine the current status of water quality in three selected fishery harbours namely Hikkaduwa, Galle, and Hambantota located in the Southern coastal stretch of the country. It also aimed to provide recommendations to prevent harbour water pollution and minimize postharvest loses due to spoilage and finally to upgrade the quality of fish for human consumption.

\section{Methodology}

\section{Study Area}

Figure 1 shows the map of study sites, illustrating selected sampling locations from the each site.

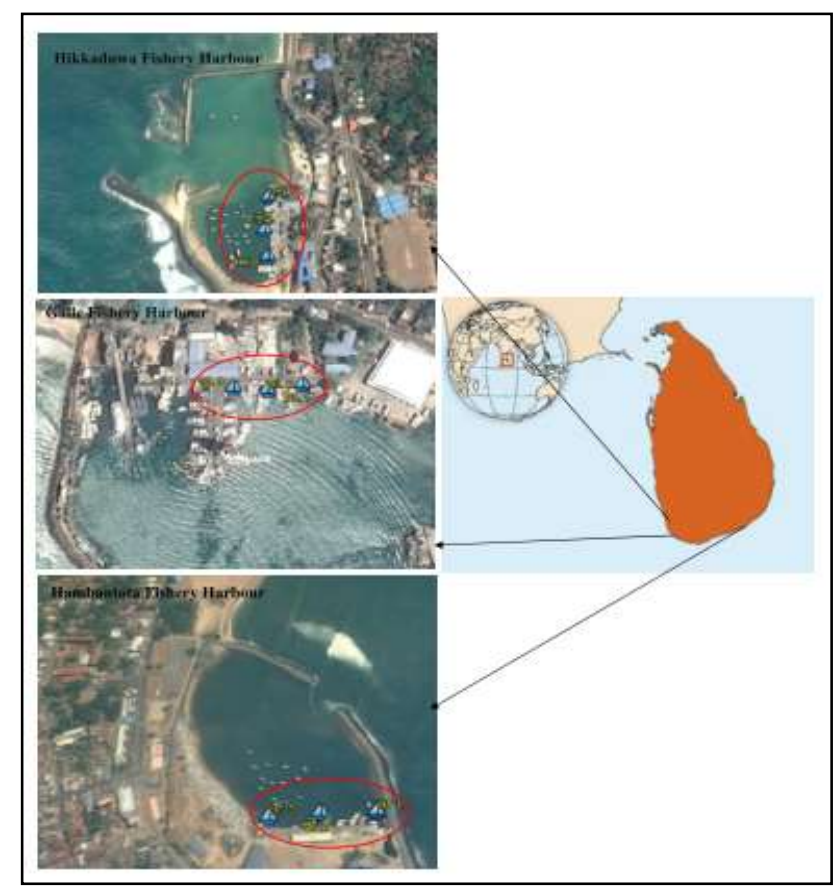

Figure 1: Map of the study site

Three sampling locations from each fishery harbour were selected using random sampling techniques.

\section{Study Period}

Field visits were carried out for three months period from May to July 2014. 


\section{Sample Collection and Laboratory Analysis}

Total of 14 physicochemical parameters of water quality were measured to identify the pollution levels. Water temperature, $\mathrm{pH}$, electrical conductivity (EC), total dissolved solids (TDS), salinity, dissolved oxygen (DO), and turbidity of the water samples were measured in-situ .Portable meters were used in-situ viz. $\mathrm{pH}$ (Orion 260A), EC, TDS and salinity (Hanna multi range conductivity meter, HI 8733), DO (Orion 830A), and turbidity ( Hach 2100P).

All the water samples collected were preserved and transported to the laboratory at $4{ }^{\circ} \mathrm{C}$. Biochemical oxygen demand (BOD), chemical oxygen demand (COD), ammonia-N, nitrate-N, nitrite-N, orthophosphate and oil \& grease were analysed according to standard procedures of Examination of Water and Waste Water, 20th edition (APHA, 1998).

Sealed, pre sterilized polypropylene bottles were used to take water samples for fecal coliform assessments to evaluate microbial contaminations and assessment was carried out in Inland Post Harvest Technology Division of NARA.

\section{Data Analysis}

One - way analysis of variance (ANOVA) and Microsoft excel 2007 was used to analyse physicochemical parameters of water.

\section{Results and Discussion}

Table 1: Summary of the results of the study area

\begin{tabular}{cccc}
\hline Parameter & Hikkaduwa & Galle & Hambantota \\
\hline pH & $7.37 \pm 0.42$ & $7.33 \pm 0.47$ & $7.40 \pm 0.53$ \\
Water Temperature $\left({ }^{\circ} \mathrm{C}\right)$ & $30.9 \pm 0.8$ & $30.0 \pm 0.5$ & $31.6 \pm 0.6$ \\
DO $(\mathrm{mg} / \mathrm{L})$ & $5.90 \pm 0.86$ & $7.60 \pm 0.97$ & $7.13 \pm 0.72$ \\
EC $(\mathrm{mS} / \mathrm{cm})$ & $53.21 \pm 1.42$ & $51.88 \pm 1.59$ & $52.66 \pm 3.08$ \\
Salinity (ppt) & $35.17 \pm 0.69$ & $33.80 \pm 1.62$ & $36.60 \pm 1.99$ \\
TDS (g/L) & $31.09 \pm 0.78$ & $30.10 \pm 1.55$ & $31.73 \pm 0.64$ \\
Turbidity (NTU) & $9.44 \pm 0.12$ & $8.63 \pm 0.57$ & $8.62 \pm 2.67$ \\
BOD $(\mathrm{mg} / \mathrm{L})$ & $9.67 \pm 0.70$ & $7.10 \pm 0.43$ & $9.17 \pm 0.25$ \\
COD $(\mathrm{mg} / \mathrm{L})$ & $719.51 \pm 61.63$ & $926.5 \pm 93.5$ & $840.2 \pm 104.8$ \\
Oil \& Grease $(\mathrm{mg} / \mathrm{L})$ & $13.1 \pm 0.6$ & $17.9 \pm 0.2$ & $17.8 \pm 1.2$ \\
Ammonia - N (mg/L) & $0.85 \pm 0.35$ & $0.77 \pm 0.20$ & $0.88 \pm 0.06$ \\
Nitrate $-\mathrm{N}(\mathrm{mg} / \mathrm{L})$ & $0.55 \pm 0.03$ & $0.54 \pm 0.18$ & $0.43 \pm 0.36$ \\
Nitrite $-\mathrm{N} \mathrm{mg/L}$ & $0.03 \pm 0.003$ & $0.02 \pm 0.011$ & $0.03 \pm 0.017$ \\
Ortho phosphate $(\mathrm{mg} / \mathrm{L})$ & $0.39 \pm 0.2$ & $0.96 \pm 0.05$ & $0.38 \pm 0.03$ \\
Fecal Coliforms / MPN per 100mL & 1633 & 2400 & 2400 \\
\hline
\end{tabular}


Average BOD $(9.67 \pm 0.70),(7.10 \pm 0.43),(9.17 \pm 0.25) \mathrm{mg} / \mathrm{L}, \mathrm{COD}(719.51 \pm$ 161.63), (926.50 \pm 93.50$),(840.20 \pm 104.80) \mathrm{mg} / \mathrm{L}$, and oil \& grease $(13.1 \pm 0.60)$, $(17.90 \pm 0.20),(17.80 \pm 1.20) \mathrm{mg} / \mathrm{L}, \quad$ in Hikkaduwa, Galle, and Hambantota showing high level of water pollution of the harbours as indicated in Table 1 and, Figures 2,3 and 4.

Water quality can be used to describe the physical, chemical and biological characteristics and conditions of water and aquatic ecosystems that directly impact on the ability of water to support for the designated uses (Anon, n. d.). Coastal water quality is mostly influenced due to natural, geological and oceanographic processes, as well as by both marine and land based human activities (Environment Canada, 2000). It is estimated, however, that $80 \%$ of coastal pollution results due to land based activities.

Biochemical Oxygen Demand (BOD), it is an important indicator of overall water quality and may be originated naturally or by addition of organic matter into water ways (EPA, 2001). According to the results obtained, mean concentration of BOD in Hikkaduwa fishery harbour was $9.67 \pm 0.7 \mathrm{mg} / \mathrm{L}$ as indicated above while minimum and maximum values recorded as $6.30 \mathrm{mg} / \mathrm{L}$ and $12.90 \mathrm{mg} / \mathrm{L}$ respectively. There was slight increase of BOD value of Hikkaduwa fishery harbour compared with the previous studies (De Alwis et al., 1994; Wickramaarchchi and Sureshkumar, 2007).

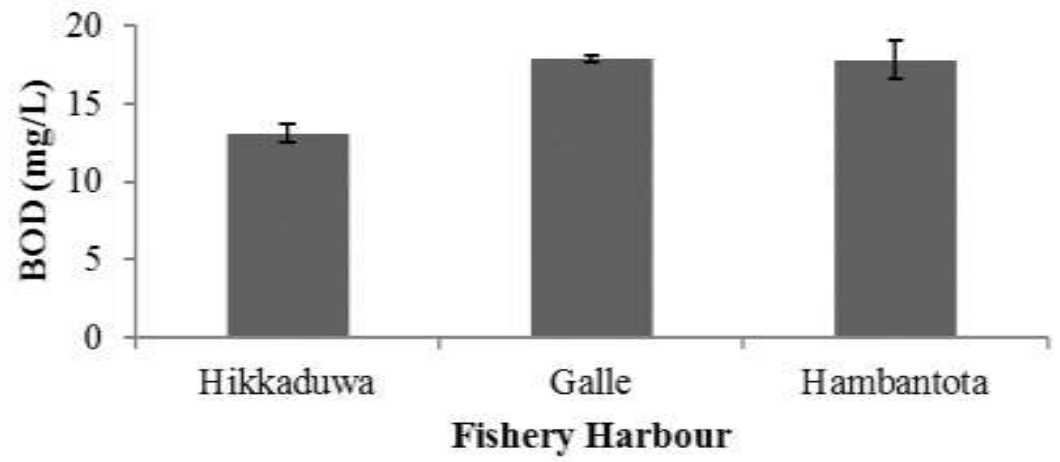

Figure 2: Variation of Mean BOD in study area

Galle fishery harbour indicated $(7.10 \pm 0.43) \mathrm{mg} / \mathrm{L}$ mean BOD concentration with the minimum of $4.90 \mathrm{mg} / \mathrm{L}$ and maximum of $10.30 \mathrm{mg} / \mathrm{L}$. Hambantota fishery harbour indicated $(9.17 \pm 0.25) \mathrm{mg} / \mathrm{L}$ mean BOD concentration with the minimum of $5.60 \mathrm{mg} / \mathrm{L}$ and maximum of $9.20 \mathrm{mg} / \mathrm{L}$. Therefore it was revealed that, average concentrations of BOD in all the fishery harbours were above the recommended value $(<4 \mathrm{mg} / \mathrm{L})$ of environmental quality standards by Central Environmental Authority of Sri Lanka and primary water quality criteria for class SW-IV harbour (03mg/L) (Niroshana et al., 2013). Disposal of solid wastes including fish offal, food waste and inadequate waste receiving facilities may be the most possible reason to record these high $\mathrm{BOD}$ values. 
A measurement of the oxygen depletion capacity of water contaminated with organic waste matter is called as COD, which measures the equivalent amount of oxygen required to chemically oxidize organic compounds in water (EPA, 2001).

Compared to the other two study sites, Galle fishery harbour indicated the highest mean value of COD with the minimum of $600 \mathrm{mg} / \mathrm{L}$ and the maximum of 1061.72 $\mathrm{mg} / \mathrm{L}$. The lowest mean COD value was recorded from the Hikkaduwa fishery harbour with minimum of $400 \mathrm{mg} / \mathrm{L}$ and the maximum of $912 \mathrm{mg} / \mathrm{L}$. Minimum and maximum COD values of Hamabantota fishery harbour were $695 \mathrm{mg} / \mathrm{L}$ and 935 $\mathrm{mg} / \mathrm{L}$ respectively.

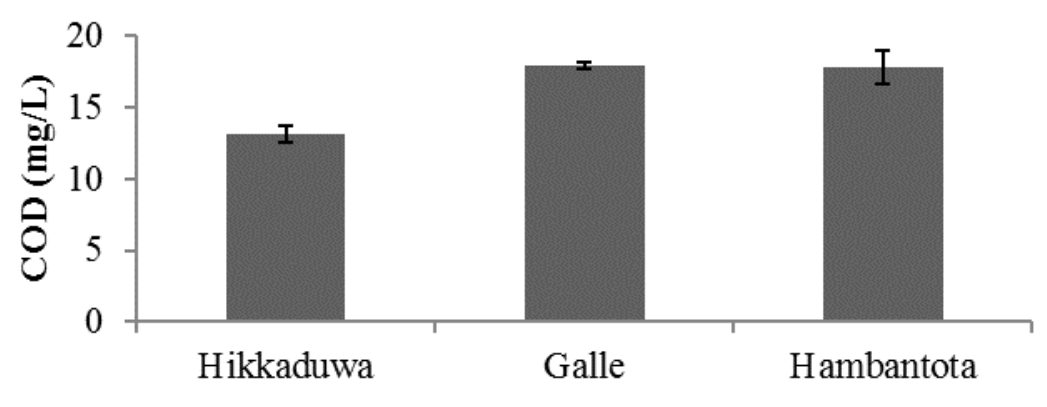

Fishery Harbour

\section{Figure 3: Variation of Mean COD in study area}

According to the overall results, COD values of the all fishery harbours were nearly three times higher than the acceptable limit $(250 \mathrm{mg} / \mathrm{L})$.

Residual food waste from bottles and cans, antifreeze, emulsified oils are all high in COD and are common sources of COD. Accumulations of most of these waste materials were observed during field surveys at many places in the harbours and that may be the possible reason to these recorded high COD values during the study period.

According to the previous study carried out by Namarathna and Dassanayake (1991), a small stream called "Modaela" flowing into the Galle fishery harbour from the eastern discharging effluents which contain high level of chemicals. It may be the most possible reason to record high COD value from the Galle fishery harbour over the time.

Fisheries harbour a possible place for oil accumulation than the other coastal regions due to anchorage of fishing vessels. Major ways of oil pollution is possible in the harbour basin due to leakages of transferring fuel, vessels pump out bilge water which contaminated with oil, waste oil and fuel residues and also due to accidentally oil spillages in ports (Dassanayake, 1994). 
According to the results obtained, Galle fishery harbour indicated the highest mean value of oil \& grease with the minimum and maximum from $11.6 \mathrm{mg} / \mathrm{L}$ to 24.8 $\mathrm{mg} / \mathrm{L}$. Hambantota fishery harbour indicated slightly low value than the Galle fishery harbour, which varied from $10 \mathrm{mg} / \mathrm{L}$ to $29 \mathrm{mg} / \mathrm{L}$. Oil \& grease content of the Hikkaduwa fishery harbour varied from 11.5 to $15.0 \mathrm{mg} / \mathrm{L}$. Although, the lowest oil $\&$ grease content was recorded from the Hikkaduwa fishery harbour, it is indicated the increasing trend of oil \& grease when compared to the previous study carried out by Sureshkumar and Wicramarachchi in 2007 which indicated the mean value of $6.5 \pm 4.83 \mathrm{mg} / \mathrm{L}$.

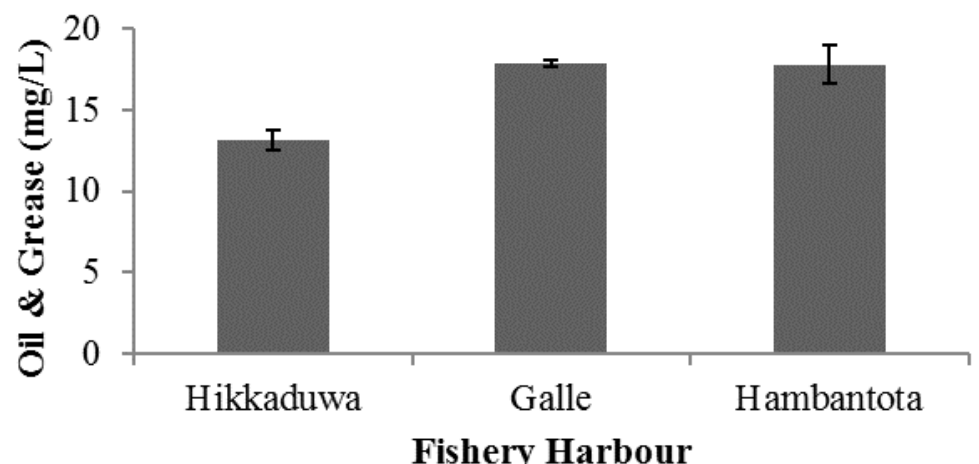

Figure 4: Variation of mean oil \& grease content in study area

Oil and grease includes a wide array of hydrocarbon compounds, some of which are toxic to aquatic organisms at low concentrations. (California Storm water Quality Association, 2003).Oil contamination is negatively effect on aquatic organisms by clogging of gills of and causing anoxia due to poor oxygen exchange between the atmosphere and the surface water. According to the primary water quality criteria for class SW-IV harbour water recommended value for the oil and grease content is $10 \mathrm{mg} / \mathrm{L}$.

Emission of engine oil from fishing vessels, occasional discharges of oils and sledges from the adjacent industries, accidental oil spillage during the refueling activities may be the possible reasons for observing high oil \& grease content in the study sites.

MPN values of fecal coliforms (per $100 \mathrm{ml}$ ) were ranged between 1633 and 2400, which also exceeded the recommended standards for harbour waters. The presence of fecal coliform bacteria in these harbour waters indicates that the water has been contaminated with the fecal material of man or other animals. This may be mostly due to waste water outfalls connected to the canals from the residential areas which enter the harbour premises.

These pathogens can be accidentally swallowed with water or eaten in contaminated shellfish. It can also be affected to human through small cuts, scratches or mucus membranes when they were exposed to the contaminated water (Anon, 2005). 
On the other hand, the quality of fish may be deteriorated due to contaminated water, which is directly caused to biological losses causing bacterial infestations, post-harvest loses which cannot be restored by processing. Once the quality is of fish is lost, only low-grade fish is left for consumers (Alles et al., 1980). Therefore improve the standards of fishery industry is must to reduce post-harvest losses through pollution prevention to improve the quality of fish.

One - way ANOVA statistical method was carried out to identify the variations between the important physico - chemical parameters between sites of each harbour. When considering the Hikkaduwa fishery harbour, Turbidity, Ammonia, Nitrite, BOD, COD values were significantly different among sites while all the other parameters were not having significance variation (Table 2). The site 1 of the Hikkaduwa fishery harbour was very close to the main complex and there were no direct discharges of waste into the harbour. This might be the reason for high turbidity and low BOD and COD values in location 1.

Table 2: Hikkaduwa FH site comparison for important parameters

\begin{tabular}{ccccc}
\hline Parameter & H1 & H2 & H3 & P value \\
\hline PH & $7.40 \pm 0.39$ & $7.37 \pm 0.34$ & $7.33 \pm 0.36$ & 0.92 \\
Turbidity ( NTU) & $9.94 \pm 0.12$ & $9.52 \pm 0.07$ & $8.67 \pm 0.5$ & 0.01 \\
Ammonia (mg/L) & $0.48 \pm 0.09$ & $0.64 \pm 0.06$ & $1.30 \pm 0.06$ & 0.00 \\
Nitrite $(\mathrm{mg} / \mathrm{L})$ & $0.02 \pm 0.001$ & $0.01 \pm 0.001$ & $0.02 \pm 0.09$ & 0.00 \\
Phosphate $(\mathrm{mg} / \mathrm{L})$ & $0.40 \pm 0.28$ & $0.44 \pm 0.02$ & $0.39 \pm 0.17$ & 0.93 \\
Oil \&grease (mg/L) & $12.6 \pm 0.88$ & $16.69 \pm 4.78$ & $14.38 \pm 0.84$ & 0.68 \\
BOD (mg/L) & $6.18 \pm 0.34$ & $10.48 \pm 0.61$ & $11.08 \pm 1.32$ & 0.00 \\
COD (mg/L) & $601.8 \pm 164.1$ & $731.1 \pm 148.6$ & $825 \pm 86.6$ & 0.01 \\
\hline
\end{tabular}

Same as according to the $\mathrm{P}$ values obtained for the sites of Galle fishery harbour, only Ammonia, BOD, and COD parameters showed significantly different values among the stations (Table 3). There were high solid waste accumulation in site 2 and 3 and high fecal contamination in middle of the jetty area. Same as nitrogen waste discharge from vessels and organic waste decomposition also can be found in site 3. Therefore, collectively those reasons might lead to high BOD and COD values in Galle fishery harbour. 
Table 3: Galle FH site comparison for important parameters

\begin{tabular}{ccccc}
\hline Parameter & G1 & G2 & G3 & P value \\
\hline PH & $7.01 \pm 0.23$ & $7.51 \pm 0.63$ & $7.24 \pm 0.33$ & 0.07 \\
Turbidity( NTU) & $9.01 \pm 0.39$ & $8.17 \pm 0.98$ & $7.93 \pm 0.8$ & 0.28 \\
Ammonia (mg/L) & $0.63 \pm 0.01$ & $0.64 \pm 0.12$ & $0.87 \pm 0.23$ & 0.02 \\
Nitrite $(\mathrm{mg} / \mathrm{L})$ & $0.16 \pm 0.01$ & $0.014 \pm 0.02$ & $0.02 \pm 0.02$ & 0.52 \\
Phosphate(mg/L) & $1.2 \pm 1.07$ & $1.27 \pm 0.26$ & $1.40 \pm 1.64$ & 0.10 \\
Oil\& grease(mg/L) & $12.55 \pm 0.88$ & $16.69 \pm 4.78$ & $14.38 \pm 0.84$ & 0.68 \\
BOD (mg/L) & $5.64 \pm 0.64$ & $6.18 \pm 0.42$ & $8.97 \pm 1.28$ & 0.00 \\
COD (mg/L) & $720.6 \pm 142.8$ & $926.5 \pm 93.5$ & $912.5 \pm 50.5$ & 0.00 \\
\hline
\end{tabular}

$\mathrm{P}$ value results obtained for the Hambantota fishery harbour COD and BOD parameters were only showed the significance variation (Table 4). This could be happened due to the accumulation of many types of solid waste such as plastics, polythene, used batteries, food waste, broken fish containers, paper, bottles, tire fenders etc., into the station 3 (closer to the main jetty where many boats are anchored) and station 2 .

Table 4: Hambantota FH site comparison for important parameters

\begin{tabular}{ccccc}
\hline Parameter & HA1 & HA2 & HA3 & P value \\
\hline PH & $7.43 \pm 0.46$ & $7.42 \pm 0.45$ & $7.35 \pm 0.46$ & 0.93 \\
Turbidity (NTU) & $7.83 \pm 0.83$ & $7.32 \pm 0.99$ & $6.99 \pm 0.72$ & 0.93 \\
Ammonia(mg/L) & $0.74 \pm 0.06$ & $0.88 \pm 0.16$ & $0.77 \pm 0.10$ & 0.42 \\
Nitrite(mg/L) & $0.012 \pm 0.01$ & $0.014 \pm 0.01$ & $6.99 \pm 0.72$ & 0.52 \\
Phosphate(mg/L) & $0.36 \pm 0.05$ & $0.55 \pm 0.03$ & $0.29 \pm 0.07$ & 0.28 \\
Oil \& grease(mg/L) & $12.55 \pm 0.88$ & $16.69 \pm 4.78$ & $14.38 \pm 0.84$ & 0.68 \\
BOD (mg/L) & $6.05 \pm 0.45$ & $7.21 \pm 1.52$ & $8.65 \pm 1.15$ & 0.00 \\
COD(mg/L) & $820.6 \pm 182.8$ & $714 \pm 132.4$ & $910.8 \pm 64.2$ & 0.00 \\
\hline
\end{tabular}




\section{Conclusion}

The study revealed that the water quality of the fishery harbours were degraded and are subjected to chemical pollution, oil pollution, and microbial contamination.

\section{Recommendations}

This study suggests recommendations as; develop waste receiving facility for all multiday boats in each harbour; implement tight regulations in disposal of solid wastes, waste oil and biological waste including fish offal; develop adequate infrastructure facilities to supply good quality sea water or sufficient quantities of fresh water for washing landed fish; initiate proper monitoring programmes to identify water pollution sources which discharge pollution into the inland and marine waters directly or indirectly; and aware the fisheries community on the negative impacts of harbour pollution and negative impacts due to contaminated food fish.

\section{Acknowledgements}

The authors wish to acknowledge the competent technical assistance provided by the staff of Environmental Studies Division and Institute of Post-Harvest Technology Division of NARA.

\section{References}

Alles, L. A. C., H. M. E. Herath, W. S. Wijeratne and S. Mohandas (1980). "Postharvest food losses in Sri Lanka". Report of a Workshop. pp. 51-52.

Anon. (2005). "Focus on fecal coliform bacteria from ecology's water quality program". Washington State Department of Ecology. pp. 1-2.

Anon. (n. d.). "Coastal Water Quality". Chapter 8: The State of Nova Scotia's Coast: Technical Report. .pp. 178. Available online: https://www.novascotia.ca/ coast/documents/report/Coastal-Tech-Report-Chapter8.pdf. [Accessed 08 ${ }^{\text {th }}$ October, 2015].

APHA. (1998). "Standard methods for the examination of water and waste water". $20^{\text {th }}$ Edition. APHA/AWWA/WEF.

Census of Sri Lanka. (2012). "Census of population and housing”. Provisional information based on 5\% sample. pp 1-102.

CZMP (1990). “Coastal Zone Management Plan”. Sri Lanka Coast Conservation Department Colombo, Sri Lanka. pp. 1-2.

Dassanayake, H. (1994). “An environmental assessment of the bay of Bengal region”. Bay of Bengal Programme. pp. 209-225. 
De Alwis, P., N. H. Dassanayake and Azmy S. A. M. (1994). Report on water quality aspects in Hikkaduwa marine sanctuary, National Aquatic Resources Research and Development Agency, Colombo, Sri Lanka. pp. 37.

Environment Canada. (2000). Canada's National Programme of Action for the Protection of the Marine Environment from Land-based Activities (NPA). Publication EN 21204/2000E.

EPA. (2001). "Parameters of water quality, interpretation and standards, environmental protection agency". $77 . \quad$ Available online: https://www.epa.ie/pubs/advice/water/quality/Water_Quality.pdf [Accessed 09th October, 2015].

Namarathne, S. Y. and H. Dassanayake (1991). "Present conditions of three selected fishery harbours in Sri Lanka, Tangalle, Galle and Beruwala". Report submitted to Bay of Bengal Programme.

Niroshana, K. H. H., H. B. Asanthi and P. B. T. P. Kumara (2013). "An assessment of water quality and pollution in Puranawella fishery harbour, Dewinuwara, Sri Lanka". Available online: file:///C:/Users/KAWS/Downloads/6157-21804-1-PB.pdf Accessed 29th January 2015 [Accessed $18^{\text {th }}$ July, 2015].

Scoiortino, J. A. (2010). "Fishing harbour planning, construction and management". FAO Fisheries and Aquaculture Technical Paper. No. 539. Rome, FAO. pp. 1-351.

Ceylon Chamber of Commerce. (n. d.). "Fisheries Sector in Sri Lanka". pp. 3. Available online: http://regionalblog.chamber.lk/wp-content/uploads /2011/02/Fisheries-Sectorfinal-3.pdf. [Accessed 25 ${ }^{\text {th }}$ October, 2015].

Wickramaarchchi, W. D. N. and N. Sureshumar (2007). "Assessment of water pollution status in Hikkaduwa National park". Environmental Studies Division, National Aquatic Resources Research and Development Agency, Colombo. 